\title{
POSTHARVEST OF IRRADIATED TAHITI LIME FRUITS ${ }^{1}$
}

\author{
SIMONE RODRIGUES DA SILVA², DÉBORA NANCY FERNANDES BEZERRA ${ }^{3}$, \\ MEIRE MENEZES BASSAN ${ }^{4}$, TATIANA CANTUARIAS-AVILÉS ${ }^{5}$, VALTER ARTHUR ${ }^{6}$
}

\begin{abstract}
This study aimed to evaluate the postharvest quality evolution of gamma-irradiated 'Tahiti' limes. Shiny, olivegreen fruits with coarse skin $(56 \mathrm{~cm}$ equatorial diameter) harvested in commercial orchars and processed in commercial packing house line were used. In a preliminary assay, fruits harvested in April 2011 were exposed to a gamma radiation range from 0 to $750 \mathrm{~Gy}$. The 250 and 750 Gy doses negatively affected skin quality and pulp of exposed fruits. For this reason, new assays were carried out using lower doses to irradiate fruits harvested in July 2011 (off-season) and January 2012 (regular harvest period). Fruit harvested in both periods were selected and exposed to radiation doses of $0,50,100,150$, and $200 \mathrm{~Gy}$. All irradiations occurred at a rate of $0.46 \mathrm{~Gy} / \mathrm{h}$. After fruit irradiation, physical and chemical analyses were performed along a 20 -day storage period at room temperature $\left(24 \pm 1^{\circ} \mathrm{C}\right.$ and $\left.80 \pm 5 \% \mathrm{RH}\right)$. Irradiation of fruits harvested in July 2011 and January 2012 and treated with doses of up to 200 Gy did not affect the ascorbic acid content, but doses $>100$ Gy caused skin yellowing of fruits harvested on both periods. Gamma radiation at doses $\geq 50$ Gy reduced the total soluble solids content in off-season fruits. Exposure of fruits harvested in the main harvest period to radiation doses $\geq 150 \mathrm{~Gy}$ increased weight loss. Irradiation of 'Tahiti' limes at doses between 50 Gy and 700 Gy did not preserve postharvest quality during storage at room temperature. Index terms: Citrus latifolia, conservation, gamma radiation, fruit quality.
\end{abstract}

\section{PÓS-COLHEITA DE FRUTOS DE LIMA ÁCIDA ‘TAHITI’ IRRADIADOS}

RESUMO - O presente trabalho objetivou avaliar a qualidade pós-colheita de frutos de lima ácida 'Tahiti' irradiados. Frutos colhidos de pomares comerciais com casca rugosa, de cor verde oliva brilhante e diâmetro equatorial médio de $56 \mathrm{~mm}$ foram beneficiados em casa de embalagem comercial. Em ensaio preliminar foram irradiados frutos colhidos em abril de 2011 com doses de irradiação entre 0 e $750 \mathrm{~Gy}$. As doses de 250 a 750 Gy afetaram negativamente a qualidade interna e externa dos frutos. Consequentemente foram realizadas novas avaliações com doses menores de radiação para frutos colhidos em julho de 2011 (entressafra) e janeiro de 2012 (safra). Em ambas as datas, os frutos foram selecionados e submetidos às doses de 0, 50, 100, 150 e 200 Gy. Em todas as datas, foi usada taxa de irradiação de 0,46 Gy/hora. Após a irradiação, os frutos foram submetidos a análises físicas e químicas durante 20 dias de armazenamento em temperatura ambiente $\left(24 \pm 1^{\circ} \mathrm{C}\right.$ e $80 \pm 5 \%$ UR). Para os frutos colhidos em julho de 2011 e janeiro de 2012 a irradiação em dosagens de até 200 Gy não afetou o teor de ácido ascórbico, porém exposição a doses > 100 Gy causou amarelecimento da casca nos frutos de ambas as colheitas. A irradiação em dose $\geq 50$ Gy reduziu o teor de sólidos solúveis dos frutos colhidos na entressafra. Nos frutos da safra, a exposição a doses $\geq 150$ Gy aumentou a perda de massa. A irradiação de frutos de lima ácida 'Tahiti' com doses de 50 a 750 Gy não conservou os atributos de qualidade durante o armazenamento em temperatura ambiente.

Termos para indexação: Citrus latifolia, conservação, radiação gama, qualidade de fruto.

\footnotetext{
${ }^{1}$ (Paper 132-15). Received May 18, 2015. Accepted November 18, 2015.

${ }^{2}$ Teacher at the University of São Paulo, Luiz de Queiroz College of Agriculture, Department of Plant Production, P.O.Box 9, CEP 13418-900, Piracicaba, SP. Corresponding author. Email: srsilva@usp.br ${ }^{3}$ Undegraduate student, RUSP fellow (Institutional). Email- debora.bezerra@usp.br

${ }^{4}$ Master of Science in Plant Science USP / ESALQ. Email: meire.bassan@usp.br

${ }^{5} \mathrm{PhD}$ in Plant Science USP / ESALQ. Email- tatiana.cantuarias@gmail.com

${ }^{6}$ Teacher at the Center for Nuclear Energy in Agriculture (CENA), Piracicaba-SP, Brazil. E-mail: arthur@cena.usp.br
} 


\section{INTRODUCTION}

Occupying the forth position in the Brazilian fruit production ranking, 'Tahiti' lime [Citrus latifolia (Yu. Tanaka) Tanaka] is grown mostly in the state of São Paulo (SP). Although production is sold mostly in the domestic market, a significant increase in export values was observed from 1998 to 2012, especially from 'Tahiti' lime orchards in northern SP. In 2014, 73,600 fruit metric tons were produced in that region, generating an income of US\$79.9 million (CEPEA, 2015).

Quality traits such as juice, absence of skin seeds, skin thickness and fruit size are very attractive to consumers, especially for juice preparation (DURIGAN et al., 2005). The domestic market prefers smooth-skinned juicy 'Tahiti' limes, while the fruit sold in international markets must be coarse and dark green-skinned.

Many local growers have faced problems in maintaining quality standards of 'Tahiti' limes, mainly due to injuries caused during fruit harvest and commercialization, affecting fruit physical, chemical, and sensory characteristics and reducing the number of top quality fruit by as much as $69 \%$ (BASSAN et al., 2013).

One of the technologies that may be used to reduce quality defects during the postharvest period is the exposure of fruit to gamma ionizing radiation produced by cobalt $60\left(\mathrm{Co}^{60}\right)$, the synthetic radioactive isotope of cobalt obtained by high purification of non-radioactive $\mathrm{Co}^{59}$. This technique has been used to sterilize fruit or reduce the risk of contamination with pathogenic microorganisms, to disinfect vegetables affected by insects and parasites, to inhibit root emergence and to delay ripening (CRAWFORD; RUFF, 1996; SCOTT SMITH; PILLAI, 2004). By inducing minor physiological changes such as reduction of the respiratory rate and consequent fruit dehydration, radiation slows down or even stops the maturation process (GERMANO et al., 1996).

Research on citric fruit has shown that the dose of gamma radiation to be used varies with the cultivar (MILLER et al., 2000). Irradiation of 'Valencia' oranges at dose of 750 Gy successfully conserved quality indexes (NAGAI; MOY, 1985), while exposure of 'Shatang' tangerines and 'Lane Late' oranges to dose of 600-Gy negatively affected postharvest fruit conservation (ZHANG et al., 2014; MCDONALD et al., 2013).

Studies that examined other fruit species also indicated that gamma radiation plays an important role in postharvest conservation by reducing rot incidence, weight loss and ascorbic acid degradation, in addition to increasing shelf life (MAHAJAN et al., 2014; TEZOTTO-ULIANA et al., 2014; SHAHBAZ et al., 2014; TEZOTTO-ULIANA et al., 2013; SABATO et al., 2009).

The conservation of the green skin hue of 'Tahiti' limes throughout the post-harvest period is an essential aspect for successful commercialization. In this scenario, the present study evaluated the postharvest quality of 'Tahiti' limes exposed to different doses of gamma radiation and stored at room temperature.

\section{MATERIALS AND METHODS}

'Tahiti' limes (C. latifolia Tanaka) from 7-year old 'Quebra-galho' clone plants grafted onto Rangpuir lime (C. limonia Osbeck) were used. Fruits were grown in commercial groves of Itacitrus Agroindustrial e Exportadora S/A company in the municipality of Itajobi, SP $\left(21^{\circ} 19^{\prime} 05^{\prime \prime} \mathrm{S}, 49^{\circ} 03^{\prime} 16^{\prime \prime}\right.$ $\mathrm{O}, 453 \mathrm{~m}$ a.s.1.) and had a coarse, shiny green-olive skin, with mean equatorial diameter of $56 \mathrm{~mm}$.

After harvest, fruits were processed according to the standard company classification protocol (cleaning, selection, application of plant regulator, resting, waxing, fungicide application and chemical sanitation, and were packed in $5-\mathrm{kg}$ cardboard boxes). Fruits were then transported in a non-refrigerated truck to the Center for Nuclear Energy in Agriculture (CENA), University of São Paulo, Piracicaba, SP, for gamma radiation exposure. In a preliminary experiment, fruits harvested in April 2011 were treated with 0, 250, 500, and 750 Gy gamma radiation doses. However, due to the deleterious effects on fruits observed at such doses, two additional experiments were carried out with fruits harvested in July 2011 (off-season) and in January 2012 (regular harvesting period), which were then exposed to lower gamma radiation doses of 0 , 50, 100, 150, and $200 \mathrm{~Gy}$. In all three assays, 0.46 $\mathrm{Gy} / \mathrm{h}$ radiation rate was used. After irradiation, fruits were stored in the Fruit and Vegetable Postharvest Laboratory of the Department of Plant Production, ESALQ/USP under controlled temperature (24 $\left.\pm 1^{\circ} \mathrm{C}\right)$ and humidity $(80 \pm 5 \% \mathrm{RH})$ for 20 days. Storage at room temperature was conducted aiming to simulate the regular trade conditions of 'Tahiti' limes in the domestic market.

Stored 'Tahiti' limes were analyzed every 5 days along 20 days. Titratable acidity (TA) was determined by potentiometric titration with sodium hydroxide $1 \mathrm{~N}$ to $\mathrm{pH} 8.10$ (phenolphthalein end point) and expressed as percent of citric acid content 
in the juice. Total soluble solids content (TSS) was measured in a digital refractometer with automatic temperature correction to $20^{\circ} \mathrm{C}$ and expressed as ${ }^{\circ}$ Brix. Ascorbic acid (AA) levels were determined from the reduction of the 2,6-dichlorophenolindophenol sodium salt hydrate (DCFI) indicator by ascorbic acid and expressed as $\mathrm{mg} / \mathrm{g}$ dry weight. Skin color was evaluated by measuring at two opposing points on the equatorial line using a colorimeter (CR-300, Minolta) and was expressed by color index (CI) calculated using the equation proposed by JIMENEZ-CUESTA et al. (1983) $(\mathrm{CI}=1000 \mathrm{x} \mathrm{a} /(\mathrm{L} \mathrm{x} \mathrm{b})$. Weight loss of fresh fruits was assessed using an analytical scale from the difference between initial fruit weight and the weight measured at each analysis and expressed as percent variation.

A complete randomized experimental design was used based on a $4 \times 5$ factorial (doses $\mathrm{x}$ evaluation dates) for the first trial (April 2011), and on a $5 \times 5$ factorial (doses $\mathrm{x}$ evaluation dates) for trials carried out in July and January 2012. All trials considered four replicates per treatment of 10 fruits each. Since no significant interaction was observed between doses and evaluation dates in the three trials, only results obtained at the beginning (day 0 ) and end (day 20) of the storage period are presented.

For results obtained in the first trial in April 2011, polynomial and simple regression equations were estimated in order to describe the relationship between radiation dose and study variables. Data of fruit harvested in June 2011 (off-season) and January 2012 (main harvest) were submitted to parametric analysis of variance after 0 and 20 days of storage at $24 \pm 1^{\circ} \mathrm{C}$ and $80 \pm 5 \% \mathrm{RH}$. Means were compared by the Tukey test at $5 \%$-probability.

\section{RESULTS AND DISCUSSION}

The first irradiation with doses of 250, 500, and 750 Gy performed on April 2011 induced a decrease in overall fruit quality, both internal and external, as revealed by variations of TTS, AA and TA levels (Figure 1a, b, c). Fruits analyzed in July 2011 (during the off-season) and in January 2012 (regular harvest period) treated with gamma radiation doses of up to 200 Gy did not show altered AA levels after 20 days from the beginning of storage (Tables 1 and 2).

With respect to TTS, all gamma radiation doses reduced 'Brix values in the off-season 'Tahiti' limes (Table 1), but not in fruits harvested during the regular harvest period (Table 2). Higher TA values were observed on off-season fruits treated with 50 Gy, as compared with untreated fruits (Table 1).

The $250-750$ Gy dose range applied in the first trial reduced the AA levels of fruits (Figure 1b), as previously observed for 'Shatang' tangerines, in which AA levels dropped at 15 and 30 days after exposition to gamma radiation doses of 500 and 600 Gy, respectively (ZHANG et al., 2014). In the present study, 'Tahiti' limes harvested both in the regular harvest period and in the off-season and exposed to doses of up to $200 \mathrm{~Gy}$ did not show variations in AA levels (Tables 1 and 2), as reported in previous studies with 300 Gy dose irradiation on clementines (C. clementina Hort. Ex. Tanaka) and with 200, 400, and 600 Gy radiation doses on 'Lane Late' sweet oranges (C. sinensis L. Osbeck) (MAHROUZ et al., 2002; MCDONALD et al., 2013). Ascorbic acid is involved in several metabolic reactions, among them the oxidative protection of fruits. Due to the direct role of ascorbate oxidase and peroxidase enzymes, AA is one of the most difficult vitamins to be conserved (CHITARRA; CHITARRA, 2005).

Decrease in TTS levels in off-season 'Tahiti' limes after exposure to the highest gamma radiation dose (Figure 1a) and after treatment with doses ranging from 50 to 200 Gy (Table 1) was also reported for 'Pakistani' blood oranges treated with 250 and 500 Gy and also for 'Lane Late' sweet oranges exposed to 400 and 600 Gy (KHALIL ETA AL., 2009; MCDONALD et al., 2013). A study that evaluated the effect of 150,300 , and 450 Gy doses on several citrus fruit varieties 'Ambersweet', 'Hamlin', 'Navel', 'Pineapple', 'Valencia', 'Fallglo', 'Minneola', 'Murcott', 'Sunburst' and 'Temple' showed that TTS levels decreased only in 'Ambersweet' and 'Sunburst' cultivars treated with 300 and 450 Gy (MILLER et al., 2000), while dose of 150 Gy did not affect TTS levels on any of the cultivars analyzed. Sugars, especially sucrose, glucose and fructose, represent between 75 and $80 \%$ of TTS of a citrus fruit. In addition, vitamins, proteins, and amino acids are also included in this parameter, providing substrate for maintaining postharvest metabolic activities in fruits (KLUGE et al., 2002).

Lower TA values were observed in 'Tahiti' limes harvested in April 2011 and exposed to gamma radiation at doses of $250-750$ Gy (Figure 1c). A similar finding was previously reported for 'Lane Late' sweet oranges irradiated with $600 \mathrm{~Gy}$ and 'Sunburst' and 'Temple' tangerines treated with dose of 450 Gy (MACDONALDS et al., 2013; MILLER et al., 2000). Oppositely, 'Pakistani' blood oranges treated with 250 and 500 Gy had higher TA values, compared with non-irradiated fruits (KHALIL et al., 2009), as also been observed in the present study with off-season fruits exposed to 50 Gy (Table 
1). Nevertheless, 'Tahiti' limes harvested during the regular harvest period did not show any effect of gamma radiation on TA after a 20-day storage period (Table 2), as reported for 'Ambersweet', 'Hamlin', 'Navel', 'Pineapple', 'Valencia', 'Fallglo', 'Minneola' and 'Murcott' citrus fruits submitted to gamma radiation at doses of 150,300 and 450 Gy (MILLER et al., 2000). Acidity is also another important parameter that must be considered in the evaluation of citrus fruit quality. It represents the levels of citric, malic, oxalic, succinic and benzoic acids. In addition to the acidic flavor, these acids also provide citrus fruits with its characteristic smelling, since some of them are volatile compounds (KHALIL et al., 2009; CHITARRA; CHITARRRA, 2005).

Exposure of 'Tahiti' limes harvested in April 2011 to radiation doses of 250 - 750 Gy increased skin CI, as shown by a corresponding fading green hue of fruit skin (Figure $1 \mathrm{~d}$ ). A similar hue fading of red color was observed on a previous study with clementines exposed to 300 Gy of gamma radiation, compared with non-irradiated control fruits (MAHROUZ et al., 2012). Differently, no such color change was observed on 'Lane Late' sweet oranges submitted to 200, 400 and 600 Gy radiation doses (MCDONALD et al., 2013). In the present study, 'Tahiti' limes harvested both in the regular harvest period and in the off-season and exposed to 50 Gy of gamma radiation retained the characteristic green hue of skin after a 20-day room temperature storage period (Tables 1 and 2). The preservation of the dark-green hue of 'Tahiti' lime skin is essential for consumer acceptance. In this sense, if fruit skin becomes yellow, consumers tend to reject it, mainly in international markets, where specific skin esthetic features of 'Tahiti' lime are highly desirable.

Irradiation of 'Tahiti' limes harvested in April 2011 and exposed to 250 - 750 Gy radiation dose also induced weight loss after a 20-day room temperature storage period (Figure 1e). Fruits harvested during the regular harvest season and exposed to $200 \mathrm{~Gy}$ also presented lower weight due to shrinkage, compared with non-irradiated fruits (Table 2). However, fruit weight of off-season 'Tahiti' limes was not affected by gamma radiation (Table 1). Irradiation of fruits at 250 and 500 Gy doses induced weight loss in Pakistani' blood oranges (KHALIL et al., 2009), differently from results observed in this study for 'Tahiti' limes harvested in April 2011 and irradiated with $250-750$ Gy. However, a study that assessed the effect of 200, 300, 400, 500 and 600 Gy gamma radiation doses on 'Shatang' tangerines reported that 200 and 400 Gy doses induced lower fruit loss, as compared with non-irradiated fruits after 15, 30 and 45 days of cold storage. In that study, it was also reported that 500 and 600 Gy doses induced the greatest weight loss in fruits, shortening their shelf life to less than 45 days (ZHANG et al., 2014).
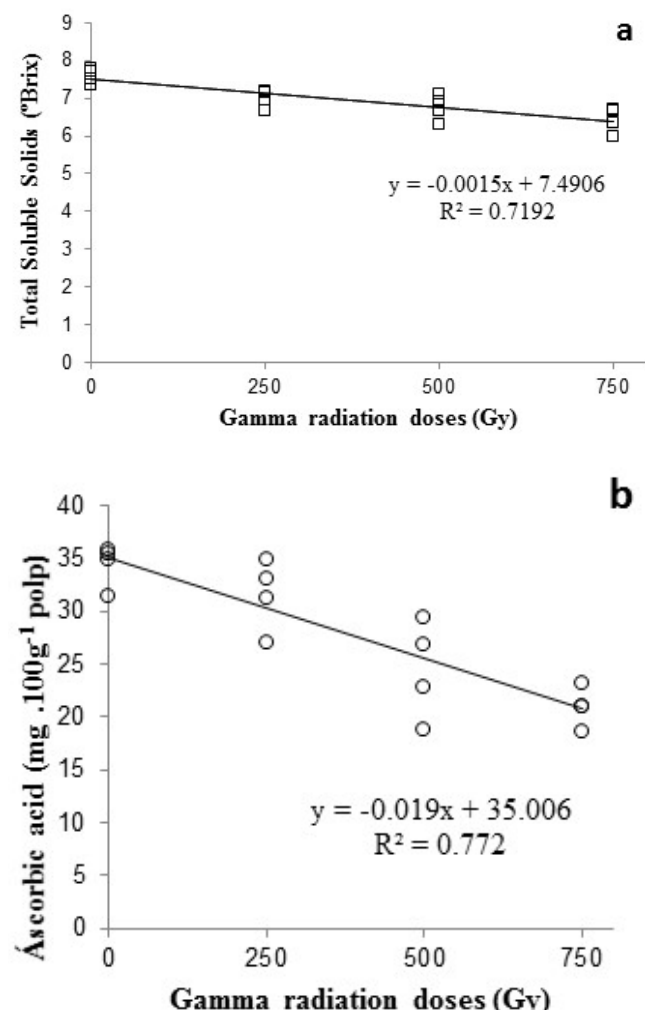

continue... 

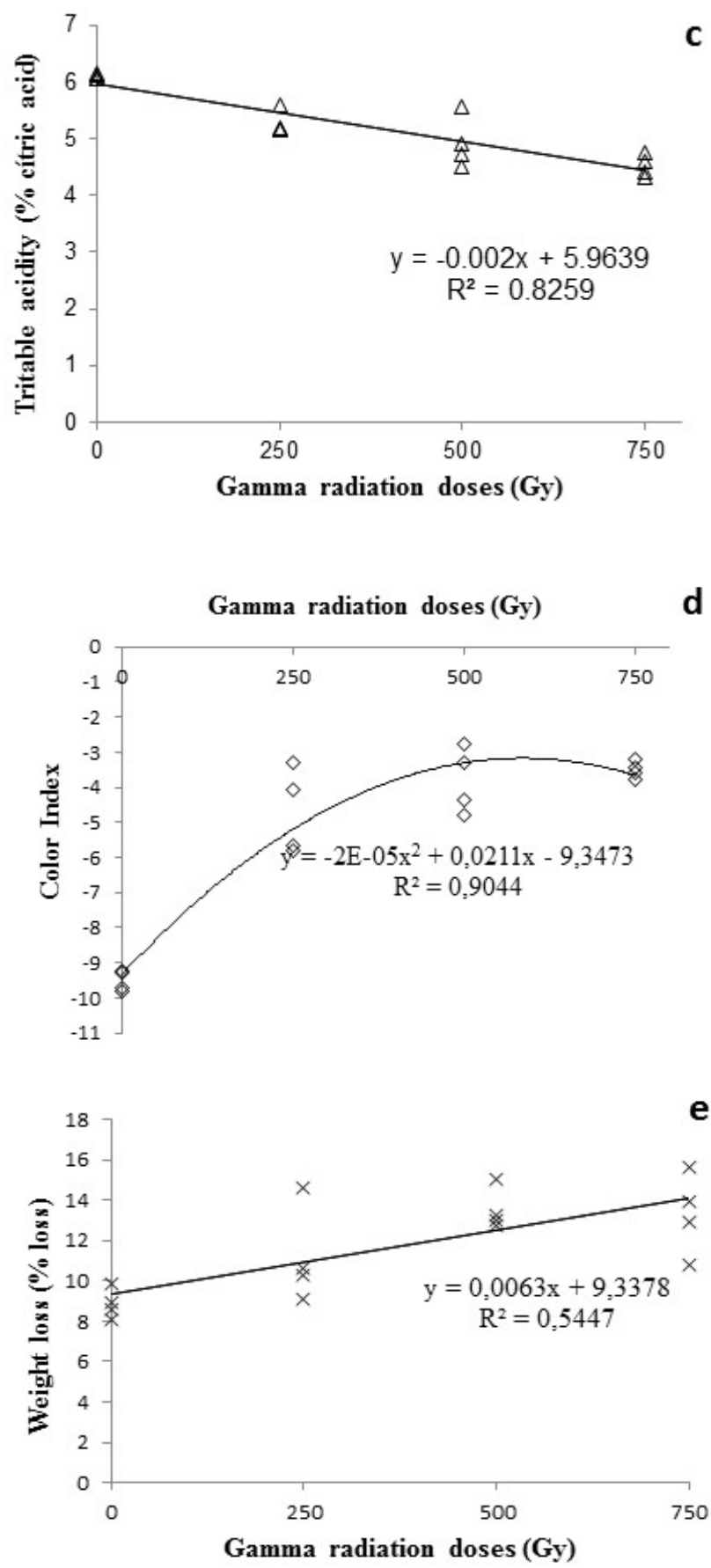

FIGURE 1- Relationship between the internal and external quality parameters of Tahiti lime picked during harvest and off season stored at $24 \pm 1^{\circ} \mathrm{C}$ and $80 \pm 5 \%$ RH for 20 days, and gamma radiation dose applied. ESALQ/USP, April, 2011. 
TABLE 1- Total soluble solids, titratable acidity, ascorbic acid, color index and fresh weight loss of offseason 'Tahiti' limes as affected by gamma radiation doses after a 20-day storage period at $24 \pm 1^{\circ} \mathrm{C}$ and $80 \pm 5 \%$ RH. ESALQ/USP, July 2011.

\begin{tabular}{|c|c|c|}
\hline \multirow{3}{*}{$\begin{array}{c}\text { Gamma radiation } \\
\text { dose (Gy) }\end{array}$} & \multicolumn{2}{|c|}{ Days at $24^{\circ} \mathrm{C}$} \\
\hline & Day 0 & Day 20 \\
\hline & \multicolumn{2}{|c|}{ Total soluble solids, TTS $\left({ }^{\circ}\right.$ Brix $)$} \\
\hline 0 & $7.83 \mathrm{a}$ & $9.13 \mathrm{a}$ \\
\hline 50 & $7.83 \mathrm{a}$ & $8.11 \mathrm{~b}$ \\
\hline 100 & $7.83 \mathrm{a}$ & $8.23 \mathrm{~b}$ \\
\hline 150 & $7.83 \mathrm{a}$ & $8.16 \mathrm{~b}$ \\
\hline 200 & $7.83 \mathrm{a}$ & $7.50 \mathrm{~b}$ \\
\hline \multirow[t]{2}{*}{$\mathrm{CV}$} & 0.00 & 4.77 \\
\hline & \multicolumn{2}{|c|}{ Titratable acidity, TA ( $\%$ citric acid $)$} \\
\hline 0 & $5.95 \mathrm{a}$ & $5.81 \mathrm{bc}$ \\
\hline 50 & $5.95 \mathrm{a}$ & $6.13 \mathrm{a}$ \\
\hline 100 & $5.95 \mathrm{a}$ & $6.06 \mathrm{ab}$ \\
\hline 150 & $5.95 \mathrm{a}$ & $5.99 \mathrm{ab}$ \\
\hline 200 & $5.95 \mathrm{a}$ & $5.54 \mathrm{c}$ \\
\hline \multirow[t]{2}{*}{$\mathrm{CV}$} & 0.00 & 2.19 \\
\hline & \multicolumn{2}{|c|}{ Ascorbic acid, AA (mg ascorbic acid/100 pulp) } \\
\hline 0 & $33.62 \mathrm{a}$ & $33.27 \mathrm{a}$ \\
\hline 50 & $33.62 \mathrm{a}$ & $35.65 \mathrm{a}$ \\
\hline 100 & $33.62 \mathrm{a}$ & $33.06 \mathrm{a}$ \\
\hline 150 & $33.62 \mathrm{a}$ & $31.53 \mathrm{a}$ \\
\hline 200 & $33.62 \mathrm{a}$ & $31.94 \mathrm{a}$ \\
\hline \multirow[t]{2}{*}{$\mathrm{CV}$} & 0.00 & 11.62 \\
\hline & \multicolumn{2}{|c|}{ Color index, CI } \\
\hline 0 & $-8.64 a$ & $-8.67 \mathrm{a}$ \\
\hline 50 & $-8.64 \mathrm{a}$ & $-9.14 \mathrm{a}$ \\
\hline 100 & $-8.64 \mathrm{a}$ & $-7.92 a b$ \\
\hline 150 & $-8.64 \mathrm{a}$ & $-7.10 b$ \\
\hline 200 & $-8.64 \mathrm{a}$ & $-6.82 b$ \\
\hline \multirow[t]{2}{*}{$\mathrm{CV}$} & 0.00 & -8.31 \\
\hline & \multicolumn{2}{|c|}{ Loss of weight $(\%)$} \\
\hline 0 & $0.00 \mathrm{a}$ & $10.09 \mathrm{a}$ \\
\hline 50 & $0.00 \mathrm{a}$ & $10.03 \mathrm{a}$ \\
\hline 100 & $0.00 \mathrm{a}$ & $9.98 \mathrm{a}$ \\
\hline 150 & $0.00 \mathrm{a}$ & $10.41 \mathrm{a}$ \\
\hline 200 & $0.00 \mathrm{a}$ & $9.69 \mathrm{a}$ \\
\hline $\mathrm{CV}$ & 0.00 & 20.85 \\
\hline
\end{tabular}

Means followed by different letters in a column indicate significant differences by the Tukey test $(\mathrm{P}<0.05)$. 
TABLE 2- Total soluble solids, titratable acidity, ascorbic acid, color index and fresh weight loss of 'Tahiti' limes picked during the harvest period as affected by different gamma radiation doses after a 20-day storage period at $24 \pm 1{ }^{\circ} \mathrm{C}$ and $80 \pm 5 \%$ RH. ESALQ/USP, January 2012.

\begin{tabular}{|c|c|c|}
\hline \multirow{3}{*}{$\begin{array}{l}\text { Gamma radiation doses } \\
\qquad(\mathrm{Gy})\end{array}$} & \multicolumn{2}{|c|}{ Days at $24^{\circ} \mathrm{C}$} \\
\hline & Day 0 & Day 20 \\
\hline & \multicolumn{2}{|c|}{ Total soluble solids, TTS $\left({ }^{\circ}\right.$ Brix $)$} \\
\hline 0 & $8.95 \mathrm{a}$ & $8.31 \mathrm{a}$ \\
\hline 50 & $8.95 \mathrm{a}$ & $8.74 \mathrm{a}$ \\
\hline 100 & $8.95 \mathrm{a}$ & $8.21 \mathrm{a}$ \\
\hline 150 & $8.95 \mathrm{a}$ & $8.06 \mathrm{a}$ \\
\hline 200 & $8.95 \mathrm{a}$ & $8.34 \mathrm{a}$ \\
\hline \multirow{2}{*}{$\mathrm{CV}$} & 0.00 & 3.92 \\
\hline & \multicolumn{2}{|c|}{ Titratable acidity, TA ( $\%$ citric acid) } \\
\hline 0 & $6.26 \mathrm{a}$ & $6.28 \mathrm{a}$ \\
\hline 50 & $6.26 \mathrm{a}$ & $6.17 \mathrm{a}$ \\
\hline 100 & $6.26 \mathrm{a}$ & $6.21 \mathrm{a}$ \\
\hline 150 & $6.26 \mathrm{a}$ & $6.08 \mathrm{a}$ \\
\hline 200 & $6.26 \mathrm{a}$ & $6.09 \mathrm{a}$ \\
\hline \multirow[t]{2}{*}{$\mathrm{CV}$} & 0.00 & 3.15 \\
\hline & \multicolumn{2}{|c|}{ Ascorbic acid, AA (mg ascorbic acid/100 g pulp) } \\
\hline 0 & $45.31 \mathrm{a}$ & $42.56 \mathrm{a}$ \\
\hline 50 & $45.31 \mathrm{a}$ & $45.49 \mathrm{a}$ \\
\hline 100 & $45.31 \mathrm{a}$ & $45.99 \mathrm{a}$ \\
\hline 150 & $45.31 \mathrm{a}$ & $43.79 \mathrm{a}$ \\
\hline 200 & $45.31 \mathrm{a}$ & $43.70 \mathrm{a}$ \\
\hline \multirow[t]{2}{*}{$\mathrm{CV}$} & 0.00 & 3.88 \\
\hline & \multicolumn{2}{|c|}{ Color index, CI } \\
\hline 0 & $-10.40 \mathrm{a}$ & $-9.53 b c$ \\
\hline 50 & $-10.40 \mathrm{a}$ & $-10.04 a b$ \\
\hline 100 & $-10.40 \mathrm{a}$ & $-10.33 \mathrm{a}$ \\
\hline 150 & $-10.40 \mathrm{a}$ & $-9.68 \mathrm{ab}$ \\
\hline 200 & $-10.40 \mathrm{a}$ & $-8.93 \mathrm{c}$ \\
\hline \multirow[t]{2}{*}{$\mathrm{CV}$} & 0.00 & -3.33 \\
\hline & \multicolumn{2}{|c|}{ Fresh weight loss $(\%)$} \\
\hline 0 & $0.00 \mathrm{a}$ & $9.41 \mathrm{~b}$ \\
\hline 50 & $0.00 \mathrm{a}$ & $9.35 \mathrm{~b}$ \\
\hline 100 & $0.00 \mathrm{a}$ & $10.29 \mathrm{~b}$ \\
\hline 150 & $0.00 \mathrm{a}$ & $10.42 \mathrm{ab}$ \\
\hline 200 & $0.00 \mathrm{a}$ & $11.47 \mathrm{a}$ \\
\hline $\mathrm{CV}$ & 0.00 & 4.98 \\
\hline
\end{tabular}

Means followed by different letters in a column indicate significant differences by the Tukey test $(\mathrm{P}<0.05)$. 


\section{CONCLUSIONS}

Irradiation of 'Tahiti' limes with gamma radiation at doses of $50-750$ Gy did not preserve fruit quality parameters during storage for 20 days at room temperature. The effect of radiation on TTS, TA and fresh weight loss varied with the period during which fruits were harvested.

\section{ACKNOWLEDGEMENTS}

The authors thank the Conselho Nacional de Desenvolvimento Científico e Tecnológico (CNPq) for the financial support and Itacitrus Agroindustrial e Exportadora S/A for the assistance and supply of fruits used in this study.

\section{REFERENCES}

BASSAN, M.M.; MOURÃO FILHO, F.A.A.; CARON, V.C.; COUTO, H.T.Z.; JACOMINO, A.P.The harvesting system affects the quality and conservation of the 'Tahiti' acid lime. Scientia Horticulturae, Amsterdam, v.155, p.72-77, 2013.

CEPEA - Centro de Estudos Avançados em Economia Aplicada-. Disponível em: $\leq$ http://www.CEPEA. esalq.usp.br/citros $>$. Acesso em: 10 jan.2015.

CHITARRA, M.I.F.; CHITARRA, A.B. Pós-colheita de frutas e hortaliças fisiologia e manejo. 2.ed. rev. ampl. Lavras: UFLA, 2005. 785p.

CRAWFORD, L. M.; RUFF, E. H. A review of the safety of cold pasteurization through irradiation.Food Control, Guildford, v.7, n.2, p.87-97, 1996.

DURIGAN, M.F.B.; MATTIUZ, B.; DURIGAN, J.F. Injúrias mecânicas na qualidade pós- colheita de lima ácida 'Tahiti' armazenada sob condição ambiente. Revista Brasileira de Fruticultura, Jaboticabal, v.27, n.3, p.369-372, 2005.

GERMANO, R.M.de A.; ARTHUR, V.; WIENDL, F.M. Conservação pós-colheita de abacates Persea americana Mill, variedade Fortuna e Quintal, por irradiação. Scientia Agrícola, Piracicaba, v.2/3, n.53, p.249-53, 1996.

JIMENEZ-CUESTA，M.; CUQUERELLA CAYUELA, J.; MARTINEZ-JAVEGA, J.M. Teoría y práctica de la desverdización de los cítricos. Madrid: INIA, 1983. 22p .(Hoja técnica, 46).
KHALIL, S.A., HUSSAIN, S., KHAN, M., KHATTAK, A.B. Effects of gamma irradiation on quality of Pakistani blood red oranges (Citrus sinensis L. Osbeck). International Journal of Food Science and Technology, Oxford, v.44, n.5, p.927-931, 2009.

KLUGE, R.A.; NACHTIGAL, J.C.; FACHINELLO, J.C. Fisiologia e manejo pós-colheita de frutas de clima temperado. 2.ed. Piracicaba: Livraria e Editora Rural, 2002. 214p.

MAHAJAN, P.V.; CALEB, O. J.; SINGH, Z.; WATKINS, C. B.; GEYER, M. Postharvest treatments of fresh produce. Philosophical Transactions of The Royal Society, London, v.372, 2014, 19 p.

MCDONALD, H.; ARPAIA, M.L.; CAPORASO, F.; OBENLAND, D.; WERE, L.; RAKOVSKI, C.; PRAKASH, A. Effect of gamma irradiation treatment at phytosanitary dose levels on the quality of 'Lane Late' navel oranges. Postharvest Biology and Technology, Amsterdam, v.86, p.91-99, 2013.

MAHROUZ, M.; LACROIX, M.; D'APRANO, G.; OUFEDJIKH, H.; BOUBEKRI, C.; GAGNON, $M$. Effect of gamma-irradiation combined with washing and waxing treatment on physicochemical properties, vitamin $\mathrm{C}$, and organoleptic quality of Citrus clementina Hort. Ex. Tanaka. Journal of Agricultural and Food Chemistry, Easton, v.50, n.25, p.7271-7276, 2002.

MILLER, W.R.; MCDONALD, R.E.; CHAPARRO, J. Tolerance of selected orange and mandarin hybrid fruit to low-dose irradiation for quarantine purposes. HortScience, Alexandria, v.35, n.7, p.1288-1291, 2000 .

NAGAI, N.Y.; MOY, J.H. Quality of gamma irradiated California Valencia oranges. Journal of Food Science, Chicago, v.50, n.1, p.215-219, 1985.

SABATO, S. F.; SILVA, J. M.; CRUZ, J. N.; BROISLER, P.O.; RELA, P.R.; SALMIERI, S.; LACROIX, M. Advances in commercial application of gamma radiation in tropical fruits at Brazil. Radiation Physics and Chemistry, Oxford, v.78, n.7-8, p.655-658, 2009.

SCOTT SMITH, J.; PILLAI, S. Irradiation and food safety. Food Technology, Chicago, v.58, n.11, p.48-55, 2004 
SHAHBAZ, H. M.; AHN, J. J.; AKRAM, K.; KIM, H. Y.; PARK, E. J.; KWON, J. H. Chemical and sensory quality of fresh pomegranate fruits exposed to gamma radiation as quarantine treatment. Food Chemistry, Reading, v.145, p.312-318, 2014.

TEZOTTO-ULIANA, J.V.; BERNO, N.D.; SAJI, F.R.Q.; KLUGE, R.A. Gamma radiation: An efficient technology to conserve the quality of fresh raspberries. Scientia Horticulturae, Amsterdam, v.164, p.348-352, 2013.
TEZOTTO-ULIANA, J.V.; SILVA, P.P.M.; KLUGE, R.A.; SPOTO, M. H. F. Radiação gama em produtos de origem vegetal. Revista Virtual de Química, Niterói, v.7, n.1, p.267-277, 2015.

ZHANG, K.; DENG, Y.; FU, H.; WENG, Q. Effects of Co-60 gamma-irradiation and refrigerated storage on the quality of Shatang mandarin, Food Science and Human Wellness, Beijing, v.3, n.1, p.9-15, 2014. 